\title{
PEMETAAN KETAHANAN PANGAN BERDASARKAN ASPEK KETERSEDIAAN PANGAN DI KOTA PEKANBARU PROPINSI RIAU
}

\author{
Mapping of Food Security Based on Aspect of Food Availability \\ in Pekanbaru City Riau Province
}

\author{
Sisca Vaulina ${ }^{1}$, Sri Ayu Kurniati ${ }^{1}$, Sri Mulyani ${ }^{2}$ \\ ${ }^{1}$ Dosen Prodi Agribisnis, Universitas Islam Riau \\ ${ }^{21}$ Dosen Prodi Agroteknologi, Universitas Islam Riau \\ Email: siscavaulina@agr.uir.ac.id \\ [Diterima: Desember 2021; Disetujui: Desember 2021]
}

\begin{abstract}
Food availability is food available from natural sources either through food production, cultivating the land, or by other of obtaining food, such as fishing or gathering food. Food availability is important and a priority for food security in Pekanbaru City. The purpose of this research is to map food security based on the aspect of food availability in Pekanbaru City. This research was conducted using the literature study method, used secondary data. Data analysis using FSQ (Food Security Quotient). The results of the study, using calculation of Food Security Quotient (FSQ) in Pekanbaru City, for variables of production and harvested area with a category is very food safe, the commodity is soybeans. Variable food needs, commodities with very safe categories are rice; sweet potato; and peanuts. The aspect of food availability in Pekanbaru City is included in category point V, which is very food safe. The food availability index in Pekanbaru City is a very food-secure condition.
\end{abstract}

Keywords: Availability food, Mapping of food, Food security Quotient (FSQ)

\section{ABSTRAK}

Ketersediaan pangan artinya pangan harus tersedia dari sumber alami baik melalui produksi pangan, penggarapan lahan atau peternakan, atau dengan cara lain untuk memperoleh pangan, seperti memancing atau mengumpulkan makanan. Ketersediaan pangan menjadi hal yang penting dan menjadi prioritas ketahanan pangan di Kota Pekanbaru. Adapun tujuan penelitian ini yaitu pemetaan ketahanan pangan berdasarkan aspek ketersediaan pangan di Kota Pekanbaru. Penelitian ini dilakukan dengan menggunakan metode studi kepustakaan. Data yang digunakan dalam penelitian ini adalah data sekunder. Analisis data menggunakan analisis FSQ (Food Security Quotient). Berdasarkan hasil penelitian, menggunakan perhitungan Food Security Quotient (FSQ) di Kota Pekanbaru, untuk variabel produksi dan luas panen dengan kategori sangat aman pangan terdapat pada komoditi kacang kedelai. Variabel kebutuhan pangan, komoditi dengan kategori sangat aman yaitu padi; ubi jalar; dan kacang tanah. Aspek ketersediaan pangan di Kota Pekanbaru termasuk ke dalam kategori V yaitu sangat aman pangan. Indeks ketersediaan pangan di Kota Pekanbaru pada kondisi sangat tahan pangan.

Kata kunci: Ketersediaan pangan, Pemetaan pangan, Food security Quotient (FSQ)

\section{PENDAHULUAN}

Ketahanan pangan merupakan suatu kondisi terpenuhinya pangan bagi negara sampai dengan perseorangan, yang tercermin dari tersedianya pangan yang cukup, baik jumlah maupun mutunya, aman, beragam, bergizi, merata, dan terjangkau serta tidak bertentangan dengan agama, keyakinan, dan budaya masyarakat, untuk dapat hidup sehat, aktif, dan produktif secara berkelanjutan (Badan Ketahanan Pangan Kementrian Pertanian, 2019). Ketahanan pangan didalam Undang-Undang Nomor 18 Tahun 2012 tentang Pangan didefinisikan sebagai kondisi terpenuhinya pangan bagi rumah tangga yang tercermin dari tersedianya pangan yang cukup, baik jumlah maupun mutunya, aman, merata, dan terjangkau. 
Dalam rangka mencapai ketahanan pangan yang berkelanjutan, Dewan Ketahanan Pangan (2015) melakukan analisa, faktor pendukung keberhasilan dalam melaksanakan ketahanan pangan yaitu dengan tiga pilar indikator ketahanan pangan diantaranya: (i) Ketersediaan Pangan; Ketersediaan pangan berhubungan dengan terpenuhinya pangan secara fisik disuatu daerah tertentu. Kondisi dimana pangan tidak terpenuhi merupakan kondisi rawan pangan. (ii) Akses terhadap Pangan; Akses terhadap pangan berkaitan terhadap kemampuan suatu rumah tangga untuk memperoleh cukup pangan, kondisi dimana individu tidak dapat membeli atau memperoleh pangan disebut dengan kondisi rawan daya beli, dan (iii) Pemanfaatan Pangan; berhubungan dengan penggunaan pangan oleh rumah tangga, dan kemampuan individu untuk menyerap dan memetabolisme zat gizi, kondisi dimana gizi dari pangan tersebut tidak terpenuhi merupakan kondisi rawan gizi.

Provinsi Riau dikenal memiliki potensi sumberdaya pertanian, yang berpotensi sebagai lumbung pangan nasional dengan harapan mampu meningkatkan ketahanan pangan nasional. Ketahanan pangan diukur berdasarkan persentase Indeks Ketahanan Pangan (IKP) per kabupaten/provinsi. Berdasarkan hasil pengukuran, IKP Propinsi Riau dikelompokkan pada kelompok 4 yang berarti bahwa Propinsi Riau termasuk ke dalam tingkat ketahanan wilayah baik. Secara rinci tersaji pada Tabel 1.

Tabel 1. Indeks Ketahanan Pangan (IKP) Kota Pekanbaru, Tahun 2019

\begin{tabular}{llcc}
\multirow{2}{*}{ No } & \multicolumn{2}{|c}{ Keterangan } & \multicolumn{2}{c}{ Tahun 2019 } \\
\cline { 3 - 4 } & & Kota Pekanbaru & Provinsi Riau \\
\hline 1 & Indeks Ketersediaan (IK) & 14,76 & 45,97 \\
2 & Indeks Keterjangkauan (IA) & 90,51 & 82,01 \\
3 & Indeks Pemanfaatan (IP) & 81,18 & 59,95 \\
Indeks Ketahanan Pangan (IKP) & 85,38 & 62,37 \\
\hline
\end{tabular}

Sumber: Badan Ketahanan Pangan Kementerian Pertanian, 2020

Berdasarkan Tabel 1, diperoleh informasi bahwa nilai IKP Kota Pekanbaru diatas rata-rata dari nilai IKP Propinsi Riau. Namun berbeda halnya jika dilihat dari setiap indeks ketahanan pangan tersebut. Untuk Indeks Ketersediaan (IK) di Kota Pekanbaru berada di kelompok paling bawah. Artinya bahwa wilayah yang masuk ke dalam kelompok tersebut adalah kabupaten/kota yang cenderung memiliki tingkat kerentanan yang lebih tinggi daripada kabupaten/kota dengan kelompok di atasnya.

Senada yang disampaikan dalam jurnal Kartini (2020), untuk merealisasikan ketahanan pangan di Propinsi Riau, pemerintah membuat Peraturan Daerah Propinsi Riau Nomor 13 Tahun 2018 tentang ketahanan pangan, pada Pasal 2 lingkup pengaturan ketahan pangan meliputi: (1) Perencanaan ketahanan pangan; (2) Ketersediaan pangan; (3) Penganekaragaman pangan; (4) Keamanan pangan; (5) Pengawasan dan pembinaan; (6) Peran serta masyarakat; (7) Kerjasama; dan (Sanksi administrasi).

Untuk memperkuat kondisi ketahanan pangan, maka lingkup ketahanan pangan didasari atas delapan point diatas. Pada kajian ini berfokus pada point kedua yaitu mengenai ketersediaan pangan (IK). Ketersediaan pangan menjadi hal yang penting, meskipun faktor ini saja tidak cukup untuk menggambarkan ketahanan pangan di suatu wilayah. Namun aspek ini menjadi point prioritas terhadap ketahanan pangan di Kota Pekanbaru khususnya. Adapun tujuan penelitian ini adalah untuk memetakan ketahanan pangan berdasarkan aspek ketersediaan pangan di Kota Pekanbaru.

\section{METODE PENELITIAN}

Penelitian ini dilakukan dengan menggunakan metode studi kepustakaan. Zed (2014), studi pustaka atau kepustakaan dapat diartikan sebagai serangkaian kegiatan yang berkenaan dengan metode pengumpulan data pustaka, membaca dan mencatat serta mengolah bahan penelitian. Penelitian dilakukan di Kota Pekanbaru, Provinsi Riau.

Data yang digunakan dalam penelitian ini adalah data sekunder. Pengumpulan data diperoleh dari instansi yang terkait dengan penelitian seperti Badan Pusat Statistik Provinsi Riau, Badan Pusat Statistik Kota Pekanbaru, Dinas Pangan Tanaman Pangan dan Hortikultura Provinsi Riau, Dinas Sosial dan Ketenagakerjaan Kota Pekanbaru, Dinas Kesehatan Kota Pekanbaru, dan Badan Ketahanan Pangan Kota Pekanbaru. 
Data yang digunakan pada penelitian ini secara rinci dapat dilihat pada Tabel 2 .

Tabel 2. Data Sekunder Penelitian

\begin{tabular}{clll}
\hline No & Variabel & & Keterangan \\
\hline 1 & Luas panen & - Padi & - Jagung \\
& & - Ubi kayu & - Ubi jalar \\
& & - Kacang tanah & - Kacang kedelai \\
\hline 2 & Produksi & - Padi & - Jagung \\
& & - Ubi kayu & - Ubi Jalar \\
& & - Kacang kedelai & - Kacang kedelai \\
\hline 3 & Kebutuhan Pangan & - Padi & - Jagung \\
& & - Ubi kayu & - Ubi Jalar \\
& & - Kacang tanah & - Kacang kedelai \\
\hline
\end{tabular}

\section{Analisis Data}

Variabel-variabel ketersediaan pangan diisi sesuai data sekunder yang ada dari lembaga dan dinas terkait pada setiap kabupaten/kota. Analisis menggunakan Teknik analisis FSQ (Food Security Quotient), yang merupakan hasil modifikasi dari metode LQ (Location Quotient). Metode LQ merupakan Teknik pengukuran yang banyak dijumpai dimodel ekonomi untuk menentukan sektor basis atau leading sector (Badan Perencanaan Pembangunan Kota, 2015). Sementara itu, FSQ merupakan Teknik pengukuran untuk menentukan variabel yang menjadi prioritas dan non prioritas pada suatu daerah dan berpengaruh terhadap indikator ketersediaan pangan. Dalam kasus FSQ variabel yang diambil bukan variabel komoditas, melainkan variabel yang berpengaruh terhadap indikator ketersediaan pangan. Persamaan umum yang digunakan dalam FSQ adalah:

$$
F S Q=\frac{X r / R V r}{X n / R V n} \text { atau } F S Q=\frac{X r / X n}{X r / R V n}
$$

Sumber: Raihan,dkk (2020)

Keterangan:

$\mathrm{Xr} \quad=$ Nilai variabel dalam kabupaten/kota
$\mathrm{Xn} \quad=$ Nilai variabel dalam Provinsi

$\mathrm{RVr}=$ Nilai variabel total dalam

kabupaten/kota

$\mathrm{RVn}=$ Nilai variabel total dalam provinsi

Nilai FSQ yang didapat akan menunjukkan tingkat kondisi ketahanan pangan suatu wilayah sesuai dengan indikatornya. Hasil perhitungan FSQ dibagi menjadi 5 kategori, dipergunakan untuk menentukan kondisi spesifik ketahanan pangan yang meliputi:

1) Nilai FSQ dari $=0,25$ termasuk ke dalam Kategori I Sangat Rawan

2) Nilai FSQ dari > 0,25 - 0,5 termasuk ke dalam Kategori II Rawan

3) Nilai FSQ dari > 0,5 - 0,75 termasuk ke dalam Kategori III Sedang

4) Nilai FSQ dari $>0,75-1$ termasuk ke dalam Kategori IV Aman

5) Nilai FSQ > 1 termasuk ke dalam Kategori V Sangat Aman

Adapun range indeks untuk menggambarkan kondisi relatif setiap aspek ketahanan pangan dijelaskan berdasarkan range indeks menurut Badan Ketahanan Pangan (2005) dapat dilihat pada Tabel 3.

Tabel 3. Indeks Kondisi Relatif Aspek Ketahanan Pangan

\begin{tabular}{ccl}
\hline Variabel Pangan & Range & \multicolumn{1}{c}{ Kategori } \\
\hline & $>0,80$ & Sangat Rawan Pangan \\
Ketersediaan Pangan & $0,64-<0,80$ & Rawan Pangan \\
& $0,48-<0,64$ & Agak Rawan Pangan \\
& $0,32-<0,48$ & Cukup Tahan Pangan \\
& $0,16-<0,32$ & Tahan Pangan \\
& $<0,16$ & Sangat Tahan Pangan \\
\hline
\end{tabular}


Setelah hasil analisis diperoleh, selanjutnya dilakukan pemetaan terhadap aspek ketersediaan pangan. Pemetaan menggunakan program ArcGIS 10.3.

\section{HASIL DAN PEMBAHASAN}

Pangan memiliki berbagai jenis komoditi, pada penelitian ini produksi pangan terbatas dari sumber pangan karbohidrat, dengan pertimbangan bahwa separuh dari kebutuhan energi per orang bersumber dari karbohidrat. Santosa dan Sudrajat (2010), ketersediaan pangan berhubungan dengan luas lahan sawah, luas lahan panen, luas tanam dan produktivitas padi Ketersediaan komoditas pangan dengan kebutuhan konsumsi beras harus seimbang. Jumlah penduduk berpengaruh terhadap ketersediaan pangan.

Pemenuhan pangan akan berkaitan dengan kesesuaian antara produksi sektor pertanian dengan kebutuhan pangan masyarakatnya. Produksi komoditas pangan di suatu wilayah bergantung pada seberapa luas panen pada tahun yang bersangkutan (Pujiati dkk, 2020).

\section{A. Ketersediaan Pangan}

Untuk ketersediaan padi di Kota Pekanbaru, dilihat dari produksi hanya terdapat di Kecamatan Rumbai Pesisir sebanyak 12,50 Ton di tahun 2019. Sementara itu, pada tahun 2020, tidak memproduksi padi. Kebutuhan pangan yakni padi (dalam hal ini beras) sebanyak 102.063,1 Ton pada Tahun 2019 dan 87.322 Ton pada Tahun 2020. Kekurangan ini terpenuhi dari kabupaten/kota/propinsi yang lain.

Produksi jagung di Kota Pekanbaru total produksi yaitu 963,17 Ton. Berdasarkan Tabel 4, dapat dilihat bahwa produksi jagung tertinggi di Kecamatan Tenayan Raya dengan total produksi sebesar 660,30 Ton, sedangkan Kecamatan Sail, Pekanbaru Kota, Sukajadi, dan Senapelan tidak terdapat produksi jagung. Total produksi jagung di Kota Pekanbaru pada tahun 2020 sebesar 963,17 Ton. Pada saat bersamaan, untuk kebutuhan jagung sebanyak 590 Ton. Artinya bahwa untuk ketersediaan jagung di Kota Pekanbaru tercukupi.

Tabel 4. Produksi Jagung Menurut Kecamatan di Kota Pekanbaru Tahun 2020

\begin{tabular}{|c|c|c|c|c|c|c|c|c|c|c|c|c|}
\hline Kecamatan & & $a$ & $b$ & $c$ & $d$ & $e$ & $f$ & $g \quad h$ & $i$ & $j$ & $l$ & Jumlah \\
\hline Produksi (Ton) & & 18,60 & 2,17 & 34,10 & 17,05 & 660,30 & 1,55 & $\begin{array}{ll}0 & 0\end{array}$ & 0 & $0 \quad 158,10$ & 71,30 & 963,17 \\
\hline & $\begin{array}{l}a(K \\
M a r \\
(\text { Kec }\end{array}$ & $\begin{array}{l}\text { Kecamatal } \\
\text { poyan Do } \\
\text { camatan } P \\
\text { ecamatan }\end{array}$ & $\begin{array}{l}\text { (n Tan } \\
\text { amai); } \\
\text { Pekan }\end{array}$ & $\begin{array}{l}a n) ; \quad b \\
(\text { Keca } \\
u \text { Kota } \\
\text { Pesisir }\end{array}$ & $\begin{array}{l}\text { Kecamat } \\
\text { atan Ter } \\
i(\text { Kecan }\end{array}$ & $\begin{array}{l}\text { tan Payur } \\
\text { nayan } R a \\
\text { matan } S u k\end{array}$ & Sek & $i) ; c(K$ & & natan Bukit & $a v a) \cdot$ & \\
\hline
\end{tabular}

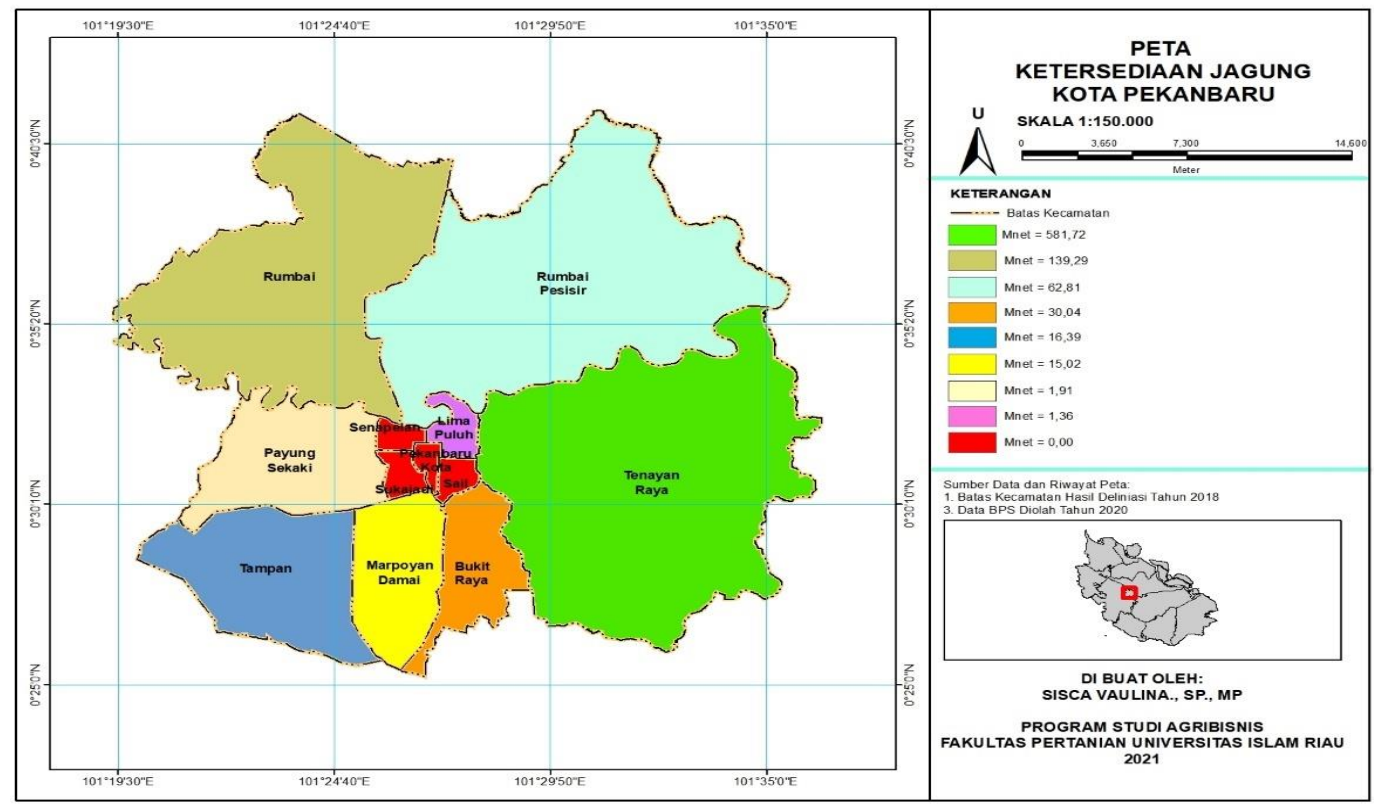

Gambar 1. Peta Ketersediaan Jagung Kota Pekanbaru, Tahun 2020 
Ubi kayu merupakan jenis tanaman pangan yang jumlah produksinya tertinggi pada tahun 2020 di Kota Pekanbaru dengan angka produksi sebesar 7.330,48 Ton. Kecamatan Tenayan Raya merupakan produsen ubi kayu terbesar di Kota Pekanbaru. Lebih jelas mengenai produksi ubi kayu di Kota Pekanbaru tahun 2020 dapat dilihat pada Tabel 5.

Tabel 5. Produksi Ubi Kayu Menurut Kecamatan di Kota Pekanbaru Tahun 2020

\begin{tabular}{|c|c|c|c|c|c|c|c|c|c|c|c|c|c|}
\hline Kecamatan & $a$ & $b$ & $c$ & $d$ & $e$ & $f$ & $g$ & $h$ & $i$ & $j$ & $k$ & $l$ & Jumlah \\
\hline $\begin{array}{l}\text { Produksi } \\
\text { (Ton) }\end{array}$ & 188,45 & 384,60 & 165,38 & 769,20 & $4.653,66$ & 19,23 & 0 & 0 & 0 & 0 & 961,50 & 188,45 & $7.330,48$ \\
\hline Keterangan: & $\begin{array}{l}a(K \\
M a r \\
(K e c \\
l(K e\end{array}$ & $\begin{array}{l}\text { natan } \\
\text { n Dan } \\
\text { tan Pel } \\
\text { atan } R\end{array}$ & bai Pest & $\begin{array}{l}\text { (Keca } \\
\text { matan } \\
\text { in } ; i(K\end{array}$ & $\begin{array}{l}\text { an Pay } \\
\text { ayan } R \\
\text { atan } S t\end{array}$ & $\begin{array}{l}e k a \\
f\end{array}$ & & & & & ukit & & \\
\hline
\end{tabular}

Berdasarkan Tabel 5 dapat dilihat bahwa produksi ubi kayu di Kota Pekanbaru tahun 2020 sebesar 7.330,48 Ton, produksi ubi kayu tertinggi di Kecamatan Tenayan Raya sebesar 4.653,66 Ton. Sedangkan Kecamatan Sail, Pekanbaru Kota, Sukajadi, dan Senapelan tidak menghasilkan produksi ubi kayu bagi Kota Pekanbaru. Dilihat dari kebutuhan pangan untuk ubi kayu sebanyak 12.390,3 Ton, artinya bahwa produksi ubi kayu di Kota Pekanbaru belum mampu memenuhi kebutuhan pangan penduduknya.

Produksi ubi jalar di Kota Pekanbaru tergolong cukup rendah, dengan jumlah produksi hanya 15 Ton. Hanya Kecamatan Bukit Raya dan Rumbai Pesisir yang mampu memproduksi ubi jalar. Sementara kebutuhan pangan untuk ubi jalar pada Tahun 2020 dengan jumlah 4.916,8 Ton. Sama halnya dengan kebutuhan pangan ubi kayu, untuk ubi jalar juga belum terpenuhi.

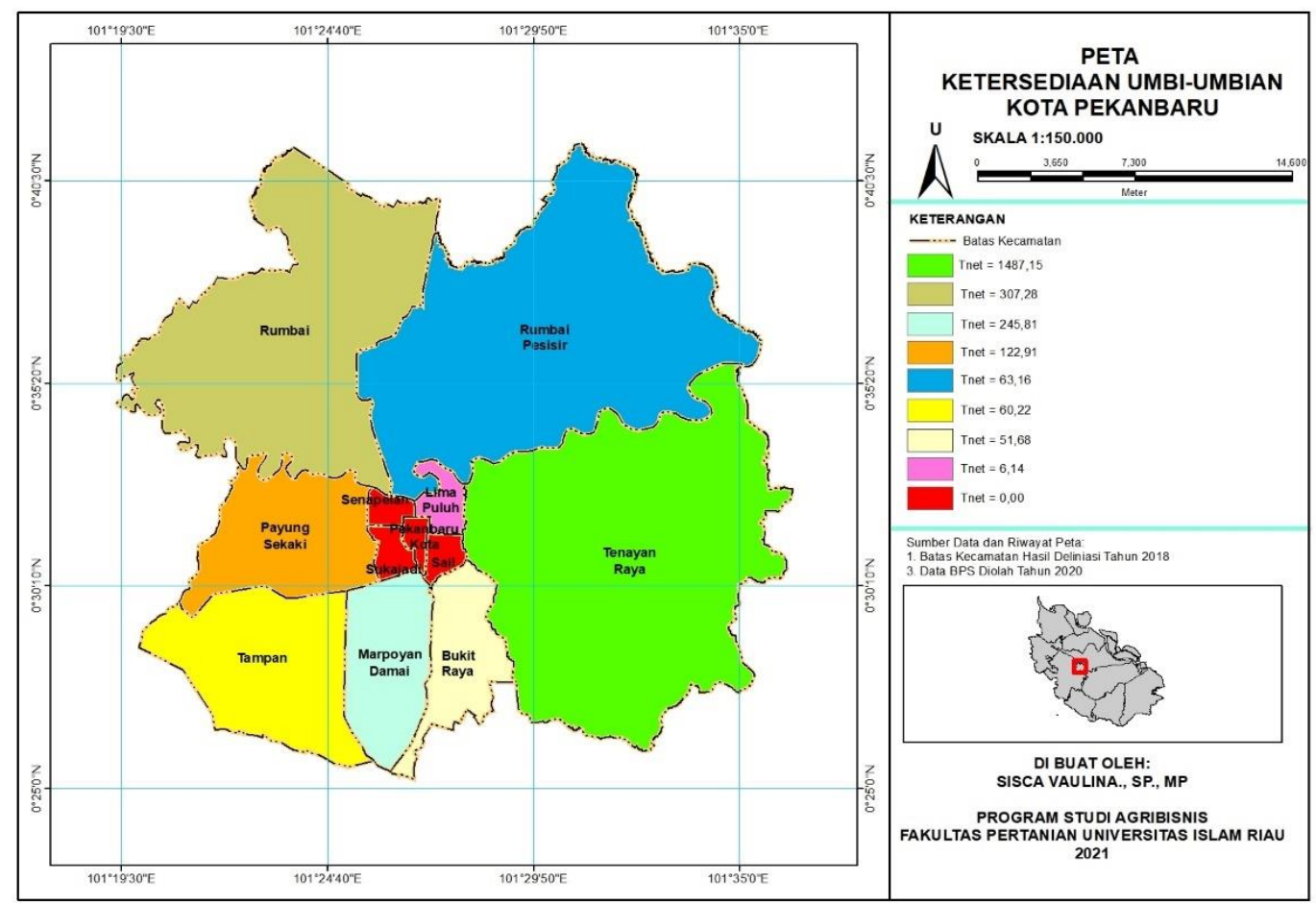

Gambar 2. Peta Ketersediaan Umbi-Umbian di Kota Pekanbaru

Produksi kacang tanah dan kacang kedelai di Kota Pekanbaru sebanyak 45,50 Ton untuk kacang tanah dan tidak terdapat produksi kacang kedelai pada tahun 2020.

Sementara itu, untuk kebutuhan pangan terhadap kacang tanah sebanyak 688,3 Ton dan kacang kedelai 5.408, 4 Ton.

\section{B. FSQ Aspek Ketersediaan Pangan}

Ketersediaan pangan adalah kondisi tersedianya pangan dari hasil produksi dalam negeri dan cadangan pangan nasional serta impor apabila kedua sumber utama tidak dapat memenuhi kebutuhan (Undang-Undang No 8 Tahun 2012). Ketersediaan pangan menitik 
beratkan pada adanya pangan secara fisik untuk memenuhi kebutuhan konsumsi pangan bagi masyarakat (Raihan, dkk, 2020).

Hasil analisis menggunakan perhitungan Food Security Quotient (FSQ) di Kota Pekanbaru, dan akan diinterpretasikan dalam bentuk tabel. Aspek ketersediaan pangan dalam penelitian ini dilihat dari variable produksi; luas panen; dan kebutuhan pangan. Sementara itu, untuk komoditi pangannya meliputi padi; jagung; ubi kayu; ubi jalar; kacang tanah; dan kacang kedelai.

Tabel 6. Hasil perhitungan FSQ pada Aspek Ketersediaan Pangan

\begin{tabular}{llrcc}
\hline No & Aspek Ketersediaan Pangan & Produksi & Luas Panen & Kebutuhan Pangan \\
\hline 1 & Padi & 0,0008 & 0,0019 & 1,0375 \\
2 & Jagung & 2,2823 & 4,1612 & 0,1072 \\
3 & Ubi Kayu & 2,2471 & 2,8106 & 0,7093 \\
4 & Ubi Jalar & 0,0110 & 0,0549 & 1,1395 \\
5 & Kacang Tanah & 0,4255 & 0,2606 & 1,1545 \\
6 & Kacang Kedelai & 7,2107 & 10,5227 & 0,9525 \\
\hline Rata-Rata & 2,0296 & 2,9685 & 0,8501 \\
\hline \multicolumn{2}{l}{ Rata-Rata Ketersediaan Pangan } & & \\
\hline
\end{tabular}

Berdasarkan Tabel 6, nilai tertinggi FSQ untuk produksi dan luas panen terdapat pada komoditi kacang kedelai yaitu 7,2107 dan 10,5227. Artinya bahwa komoditi ini termasuk pada kategori sangat aman pangan. Jika dilihat dari kebutuhan pangan dengan kepadatan penduduk 1.555 jiwa $/ \mathrm{Km}^{2}$, maka komoditi dengan kategori sangat aman yaitu padi; ubi jalar; dan kacang tanah.

Dilihat dari kisaran range nilai FSQ relatif tinggi untuk 6 komoditi pangan. Hal ini mengacu pada pengertian FSQ yang merupakan pembagian antara share terhadap share. Untuk nilai FSQ pada aspek ketersediaan pangan dengan nilai 1,9494 yang berarti bahwa secara keseluruhan kategori pangan di Kota Pekanbaru termasuk ke dalam kategori V yaitu sangat aman. Namun, saat ini kondisi ketahanan pangan menunjukkan perbedaan dengan kondisi ketahanan pangan di tingkat nasional. Ketersediaan pangan di level nasional belum tentu menjamin adanya ketersediaan pangan di level provinsi/kabupaten.

\section{Ketersediaan Pangan}

Ketersediaan pangan merupakan salah satu aspek penting dalam mewujudkan ketahanan pangan suatu wilayah. Penyediaan pangan diperlukan untuk memenuhi kebutuhan akan pangan dan gizi bagi masyarakat, rumah tangga dan perseorangan secara berkelanjutan (Atasa dan Tri, 2021). Menurut BKP (2015), dalam memenuhi kebutuhan pangan masyarakat dan meningkatkan kuntitas serta kualitas konsumsi pangan, diperlukan target pencapaian angka ketersediaan pangan per kapita per tahun. Mun'im (2012), ketahanan pangan belum tercapai saat ketersediaan pangan saja yang terpenuhi.

Tabel 7. Indeks Ketersediaan Pangan di Kota Pekanbaru Tahun 2020

\begin{tabular}{llcl}
\hline No & \multicolumn{1}{c}{ Kecamatan } & $\begin{array}{c}\text { Indeks Ketersediaan } \\
\text { Pangan }\end{array}$ & \multicolumn{1}{c}{ Kondisi Relatif Ketahanan Pangan } \\
\hline 1 & Tampan & 0,51 & Agak Rawan Pangan \\
2 & Payung Sekaki & 0,15 & Sangat Tahan Pangan \\
3 & Bukit Raya & 0,22 & Tahan Pangan \\
4 & Marpoyan Damai & 0,09 & Sangat Tahan Pangan \\
5 & Tenayan Raya & 0,01 & Sangat Tahan Pangan \\
6 & Lima Puluh & 1,00 & Sangat Rawan Pangan \\
7 & Sail & 0,00 & Sangat Tahan Pangan \\
8 & Pekanbaru Kota & 0,00 & Sangat Tahan Pangan \\
9 & Sukajadi & 0,00 & Sangat Tahan Pangan \\
10 & Senapelan & 0,00 & Sangat Tahan Pangan \\
11 & Rumbai & 0,03 & Sangat Tahan Pangan \\
12 & Rumbai Pesisir & 0,11 & Sangat Tahan Pangan \\
\hline & Jumlah & $\mathbf{0 , 0 6}$ & Sangat Tahan Pangan \\
\hline
\end{tabular}


Berdasarkan Tabel 7 diperoleh indeks ketersediaan pangan sebesar 0,06. Artinya secara keseluruhan kondisi ketahanan pangan di Kota Pekanbaru pada tahun 2020 dalam keadaan sangat tahan pangan. Hal tersebut dikarenakan rata-rata nilai ketersediaan pangan di seluruh kecamatan di Kota Pekanbaru <0,16. Hanya satu kecamatan yaitu Kecamatan Lima
Puluh dengan nilai indeks 1,00 kondisi sangat rawan pangan.

\section{Pemetaan Ketersediaan Pangan}

Pemetaan ketersediaan pangan berdasarkan pada hasil analisis indeks ketersediaan pangan. Peta ketahanan pangan tersaji pada gambar berikut.

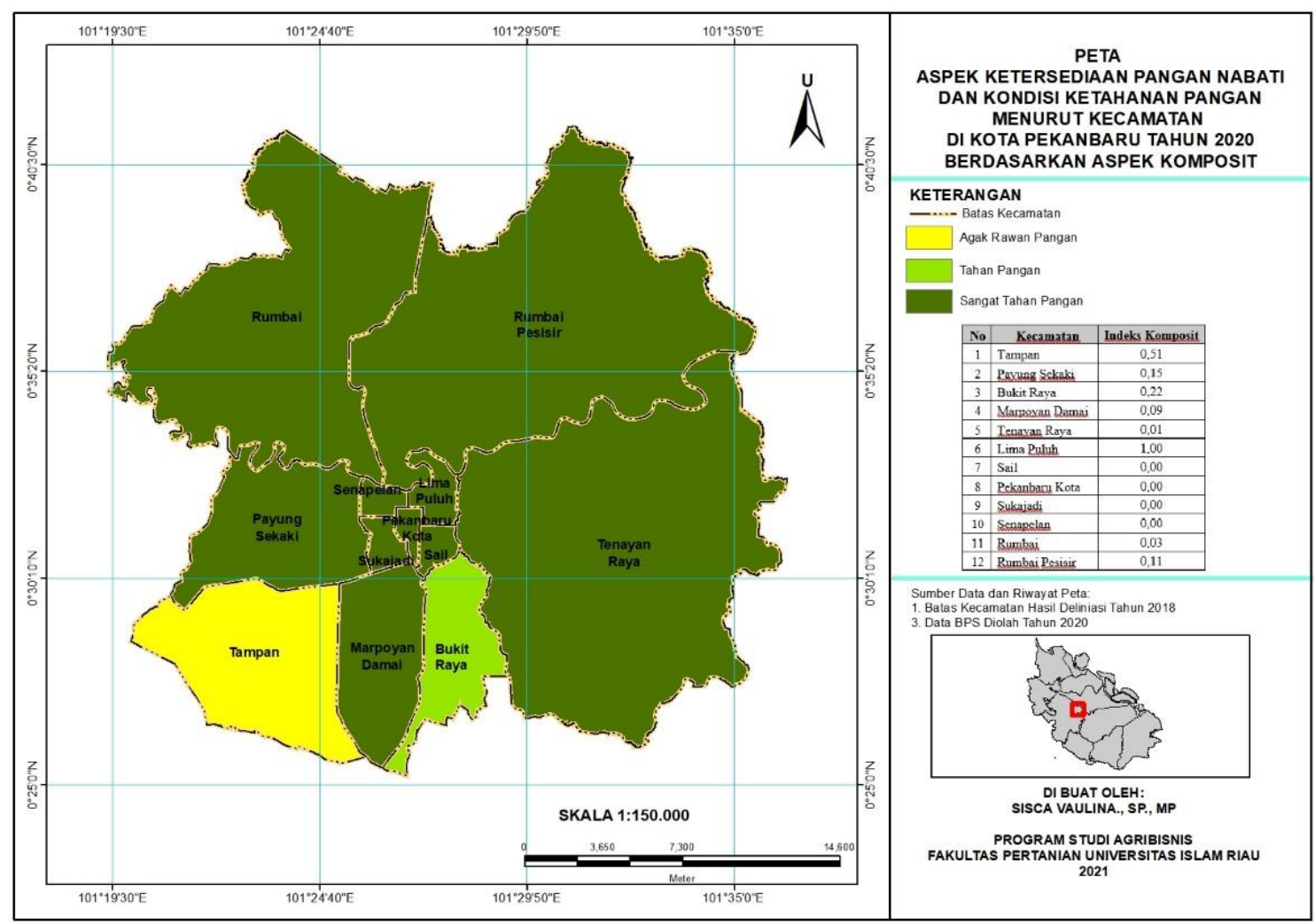

Gambar 3. Peta Ketersediaan Pangan Menurut Kecamatan di Kota Pekanbaru Tahun 2020

\section{KESIMPULAN}

Berdasarkan hasil penelitian, menggunakan perhitungan Food Security Quotient (FSQ) di Kota Pekanbaru, untuk produksi dan luas panen terdapat pada komoditi kacang kedelai yaitu 7,2107 dan 10,5227. Artinya bahwa komoditi ini termasuk pada kategori sangat aman pangan. Jika dilihat dari kebutuhan pangan dengan kepadatan penduduk 1.555 jiwa $/ \mathrm{Km}^{2}$, maka komoditi dengan kategori sangat aman yaitu padi; ubi jalar; dan kacang tanah. Untuk nilai FSQ pada aspek ketersediaan pangan dengan nilai 1,9494 yang berarti bahwa secara keseluruhan kategori pangan di Kota Pekanbaru termasuk ke dalam kategori $\mathrm{V}$ yaitu sangat aman. Indeks ketersediaan pangan di Kota Pekanbaru dengan nilai 0,06 pada kondisi relatif ketahanan pangan yakni sangat tahan pangan.

\section{DAFTAR PUSTAKA}

Atasa, D., Tri Wahyu Nugroho. 2021. Analisis Ketersediaan Pangan Kota Malang. Jurnal Pemikiran Masyarakat Ilmiah Berwawasan Agribisnis, 7(2): 11851194

Badan Ketahanan Pangan Kementerian Pertanian. 2020. Indeks Ketahanan Pangan. [Diakses pada bkp.pertanian.go.id]

Badan Ketahanan Pangan Kementrian Pertanian. 2019. Indeks Ketahanan Pangan. [Diakses pada bkp.pertanian.go.id]

Badan Ketahanan Pangan (BKP). 2015. Kajian Instrumen Kerawanan Pangan. BKP Kementrian Pertanian, Jakarta. 
Badan Ketahanan Pangan (BKP). 2015. Rencana Strategis Badan Ketahanan Pangan Tahun 2015-2019. Kementerian Pertanian, Jakarta.

Badan Ketahanan Pangan Provinsi Riau. 2005. Analisis Ketersediaan, Distribusi dan Harga Pangan. Pemerintah Daerah Provinsi Riau. Pekanbaru

Dewan Ketahanan Pangan. 2015. Peta Kerawanan Pangan Indonesia (FIA). Sekretariat Dewan Ketahanan PanganBadan Ketahanan Pangan Departemen Pertanian. Jakarta.

Elinur, E., \& Heriyanto, H. POLA PENGELUARAN PANGAN RUMAH TANGGA PETERNAK IKAN LELE DI KOTA PEKANBARU. IJAE (Jurnal Ilmu Ekonomi Pertanian Indonesia), 12(2), 135-152.

Heriyanto, H. (2016). Perilaku Konsumsi Pangan Sumber Karbohidrat Rumahtangga Petani Kelapa Sawit Di Kecamatan Kandis Kabupaten Siak. Jurnal Ilmiah Pertanian, 13(1), 22-30.

Heriyanto, H. (2018). Permintaan Pangan

Rumahtangga Provinsi Riau: Model Linear Approximate Almost Ideal Demand System. Jurnal Agribisnis, 20(2), 156-168.

Heriyanto, H. (2016). Perilaku Konsumsi

Pangan Sumber Karbohidrat

Rumahtangga Petani Kelapa Sawit Di Kecamatan Kandis Kabupaten Siak. Jurnal Ilmiah Pertanian, 13(1), 22-30.

Kartini, N. 2020. Evaluasi Kebijakan Ketahanan Pangan Di Provinsi Riau (Studi Kasus Di Kabupaten Kampar). Jom Fisip, 7 (I): 1-14

Mun'im, A. 2012. Analisis Pengaruh Faktor Ketersediaan, Akses, Dan Penyerapan Pangan Terhadap Ketahanan Pangan Di Kabupaten Surplus Pangan: Pendekatan Partial Least Square Path Modeling. Jurnal Agro Ekonomi, 30 (1): 41-58

Peraturan Daerah Propinsi Riau Nomor 13 Tahun 2018 tentang Ketahanan Pangan.
Pujiati, S., Amelia Pertiwi., Churun Cholina Silfia., Dewa Maulana Ibrahim., Siti Hadiyati Nur Hafida. 2020. Analisis Ketersediaan, Keterjangkauan Dan Pemanfaatan Pangan Dalam Mendukung Tercapainya Ketahanan Pangan Masyarakat Di Provinsi Jawa Tengah. Jurnal Sosial Ekonomi Pertanian, 16 (2): 123-133

Raihan, R. Z., Roni Kastaman., Tensiska. 2020. Menentukan Kondisi Ketahanan Pangan Jawa Barat Wilayah Iv Menggunakan Food Security Quotient (FSQ). Jurnal Ekonomi Pertanian dan Agribisnis (JEPA), 4 (1): 68-76

Santosa, S. P., dan Sudrajat. 2010. Kajian Ketersediaan dan Kebutuhan Konsumsi Beras di Kabupaten Karanganyar, Jawa Tengah. 1-11.

Undang-Undang Nomor 18 Tahun 2012. Undang-Undang (UU) tentang Pangan. Sumber: LN.2012/No. 227, TLN No. 5360, LL SETNEG: 58 HLM

Zed, M. 2014. Metode Penelitian Kepustakaan. Yayasan Pusataka Obor Indonesia, Jakarta. 